\title{
PROHIBITION OF TORTURE AND CRUEL TREATMENT IN CRIMINAL PROCEEDINGS
}

\section{Valentyna Drozd ${ }^{1}$ \\ Liudmyla Havryliuk ${ }^{2}$}

DOI: https://doi.org/10.30525/978-9934-26-050-6-25

A person, his/her life and health are recognised in the National Basic Law as the highest social value. Every person shall have the inalienable right to life and protection of human life shall be the duty of the State. In addition, everyone shall have the right to have his/her dignity respected. Accordingly, no one shall be subjected to torture, cruel, inhumane, or degrading treatment or punishment that violates his/her dignity [1]. The absolute prohibition of torture is a peremptory rule of international law and, according to the case law of the European Court of Human Rights (hereinafter referred to as the ECHR), it «reflects one of the fundamental values of a democratic society» [2].

However, despite the current level of human development and the tendency of humane solutions to conflicts, the eradication of torture is one of the most pressing issues today. According to the annual report of the Commissioner of the Verkhovna Rada for Human Rights on the state of observance and protection of the rights and freedoms of person and citizen in Ukraine for 2019, the results of the monitoring visits to the vast majority of

\footnotetext{
${ }^{1}$ State Research Institute of the MIA of Ukraine, Ukraine

${ }^{2}$ State Research Institute of the MIA of Ukraine, Ukraine
} 
places of deprivation of liberty attest to the existence of such facts [3]. In particular, acts of torture, cruel, inhuman or degrading treatment by police officers are: beatings; infliction of other bodily harm; prolonged isolation in unsuitable premises; failure to provide painkillers to critically ill patients with pain syndrome.

For example, in one of the police headquarters of the GDNP in Kiev, it was established that a detainee had been subjected to physical violence by police officers with the aim of extracting a confession to a crime. In one of the offices, the police officers beat the detainee, stretched in the manner of the 'swallow', put on a gas mask and threatened with a firearm. As a result of these actions, the detainee sustained injuries in the form of a closed chest injury, contusions, abrasions and bruises to the back [3].

It should be noted that most frequently the criminal procedure legislation of Ukraine provides specific requirements concerning human rights and freedoms and the honour and dignity of the person in regard to individual investigative or procedural actions. In particular, it is prohibited to force the accused and other persons involved in the case to testify through violence, threats or other unlawful actions. However, judicial practice analysis indicates that bodily harm is often inadequately documented or not documented at all, as provided for in the United Nations' Manual on the Effective Investigation and Documentation of Torture and Other Cruel, Inhuman or Degrading Treatment or Punishment and legal regulations in force, and no medical assistance is provided to victims.

An additional guarantee of human rights and freedoms during the pre-trial investigation is the impossibility to use evidence, obtained by the investigator (who is charged with the prosecution) in the criminal proceedings, while trying to prove his/her case against the accused, by means of coercion or oppression against the will of the accused. Accordingly, in criminal proceedings inadmissible shall be evidence obtained through significant violation of human rights and fundamental freedoms such as, torture, cruel, inhumane, or degrading treatment (Art. 87 of the CPC of Ukraine) [4].

However, judicial practice faces certain difficulties in proving that evidence has been obtained precisely through torture, cruel, inhuman or degrading treatment. For example, according to the ECHR' case law, the court shall be guided by appropriate evidence of such conduct in finding whether or not ill-treatment has occurred. In particular, this is the findings of the experts, the reports that indicate the presence of injuries and so forth. Accordingly, the proof of torture can result from the totality of signs or irrefutable facts agreed upon. It should also be noted that the absence of a record of torture of a person in an expert report or a procedural document makes it much more difficult to be proved in court. Moreover, it questions the existence of torture at all. 
It should be considered that, where an accused person claims to have been subjected to torture or cruel or inhuman treatment, the court's finding on the admissibility of evidence shall be based on a proper verification of the claim through a formal investigation.

The emphasis should be on the person's right, provided for by Art. 55 of the Constitution of Ukraine, after exhausting all domestic legal instruments, to appeal for the protection of his/her rights and freedoms to the relevant international judicial institutions or to the relevant bodies of international organisations of which Ukraine is a member or participant [1]. According to Art. 32 of the Convention for the Protection of Human Rights and Fundamental Freedoms (hereinafter referred to as the Convention), the jurisdiction of the ECHR shall extend to all matters concerning the interpretation and application of the Convention and the Protocols thereto which are referred to it as provided in Articles 33, 34, 46 and 47 of the Convention [5, p. 3]. Therefore, according to Art. 46 of the Convention, Ukraine undertakes to abide by the final judgment of the Court in any case to which it is a party.

Currently, according to Art. 17 of the Law of Ukraine «On the execution of decisions and application of the European Court of Human Rights' case law» no. 3477-IV of 23 February 2006, the courts apply the Convention and the case law of the ECHR as a source of law in proceedings. Moreover, Ukraine's criminal procedural legislation is applied considering the ECHR's case law. The analysis of its decisions reveals that the admissibility of evidence is generally a matter for national courts, that the role of ECHR is limited to assessing the overall fairness of the proceedings, that special criteria apply to evidence, obtained in a manner deemed to be in violation of Article 3 of the Convention. The admission of evidence, obtained through torture violating Article 3 of the Convention, in order to establish the relevant facts in a criminal proceeding leads to its injustice in general, regardless of their probative value and whether their use has been crucial to the conviction of the accused. For example, the ECHR's decision in the case «Gäfgen v Germany» [6].

Therefore, it should be noted that generally national courts are to decide on the admissibility of evidence, while the role of ECHR is limited to assessing the overall fairness of the proceedings, special criteria apply to evidence, obtained in a manner deemed to be in violation of Article 3 of the Convention. The admission of evidence obtained through torture violating Article 3 of the Convention in order to establish the relevant facts in criminal proceedings leads to injustice in general, regardless of their probative value and whether their application has been crucial to the conviction of the accused. 


\section{References:}

1. Konstytutsiia Ukrainy [The Constitution of Ukraine] (No. 254/96-VR of 28 June 1996). Retrieved from: https://zakon.rada.gov.ua/laws/show/254\%D0\%BA/96\%D0\%B2\%D1\%80 (accessed 02 February 2021). (in Ukrainian)

2. Akhtyrska N.M., Kasko V.V., Malanchuk B.A., Melikian A., Poshva B.M., Fulei T.I., Shuklina N.H. (2011) Zastosuvannia v Ukraini yevropeiskykh standartiv protydii zhorstokomu povodzhenniu i bezkarnosti: naukovo-praktychnyi posibnyk dlia suddiv [Application in Ukraine of European standards for combating ill-treatment and impunity: Scientific and practical guide for judges] (ed. Maliarenko V.T.). K. : K.I.S. (in Ukrainian)

3. Shchorichna dopovid Upovnovazhenoho Verkhovnoi Rady Ukrainy z prav liudyny pro stan doderzhannia ta zakhystu prav i svobod liudyny i hromadianyna $\mathrm{v}$ Ukraini za 2019 rik [Annual report of the Commissioner of the Verkhovna Rada for Human Rights on the state of observance and protection of the rights and freedoms of person and citizen in Ukraine for 2019].

4. Kryminalnyi protsesualnyi kodeks Ukrainy [Criminal Procedure Code of Ukraine] (No. 4651-VI of 13 April 2012). Retrieved from: https://zakon.rada.gov.ua/ laws/show/4651-17 (accessed 02 January 2021). (in Ukrainian)

5. Rishennia Jevropeisikoho sudu z prav liudyny 2016-2018 [2016-2018 Judgements of European Court of Human Rights]. Kyiv: Centr uchbovoi literatury. (in Ukrainian)

6. European Court of Human Rights (Judgement of 01 June 2010) Gäfgen v Germany (Application no. 22978/05). Retrieved from: http://www.alppp.ru/court/ vysshie-sudy/06-2010/informacija-o-postanovlenii-espch-ot-01-06-2010-po-delugefgen--protiv-germanii-zhaloba--2.pdf (accessed 05 February 2021). 